Proceedings

\title{
Synthesis of Peptaibolin, an Antimicrobial Peptide ${ }^{\dagger}$
}

\author{
Ana R. M. Ribeiro ${ }^{1}$, Helena P. Felgueiras ${ }^{2, *}$, Susana P. G. Costa ${ }^{1}$ and Sílvia M. M. A. Pereira-Lima ${ }^{1, *}$ \\ 1 Chemistry Research Centre (CQ), University of Minho, 4710-057 Braga, Portugal; \\ rita.ribeiro_02@hotmail.com (A.R.M.R.); spc@quimica.uminho.pt (S.P.G.C.) \\ 2 Centre for Textile Science and Technology (2C2T), University of Minho, 4710-057 Braga, Portugal \\ * Correspondence: helena.felgueiras@2c2t.uminho.pt (H.P.F.); silviap@quimica.uminho.pt (S.M.M.A.P.-L.) \\ + Presented at the 1st International Electronic Conference on Pharmaceutics, 1-15 December 2020; \\ Available online: https://iecp2020.sciforum.net/.
}

Citation: Ribeiro, A.R.M.;

Felgueiras, H.P.; Costa, S.P.G.;

Pereira-Lima, S.M.M.A. Synthesis of

Peptaibolin, an Antimicrobial

Peptide. Proceedings 2021, 78, 47.

https://doi.org/10.3390/

IECP2020-08654

Published: 1 December 2020

Publisher's Note: MDPI stays neutral with regard to jurisdictional claims in published maps and institutional affiliations.

Copyright: (c) 2020 by the authors. Licensee MDPI, Basel, Switzerland. This article is an open access article distributed under the terms and conditions of the Creative Commons Attribution (CC BY) license (http://creativecommons.org/licenses /by/4.0/).

\begin{abstract}
To tackle one of the biggest global health problems, the resistance of microorganisms to antibiotics, a collective effort in the search for more effective agents against bacteria was required. Peptides with antimicrobial activity have been raising much attention as a promising alternative for antibiotics. Peptaibols, for instance, are a family of antimicrobial peptides (AMPs) with great biomedical potential, in which the Peptaibolin can be highlighted. This peptide has gained relevance due to its small amino acids content, only four, and its acetyl group and a phenylalaninol residue (Phol) at the $N$-terminal and $C$-terminal, respectively. Here, we report the synthesis of Peptaibolin through Solid Phase Peptide Synthesis assisted by Microwave heating (MW-SPPS) in a pre-loaded Phe-Wang resin. Starting from a loading of $0.51 \mathrm{mmol} / \mathrm{g}$, two syntheses were made, using two different combinations of coupling reagents. The best option was DIC/Oxima, achieving a yield of $50.0 \%$. Proton Nuclear Magnetic Resonance ( $\left.{ }^{1} \mathrm{H}-\mathrm{NMR}\right)$ studies confirmed the peptide structure, while High Performance Liquid Chromatography (HPLC) verified the peptide purity. The peptide solubility was examined against several combinations of solvents. Peptaibolin was not soluble in water, only in organic solvents or in the combination of both. Antimicrobial testing was conducted using Staphylococcus aureus, Staphylococcus epidermidis, Escherichia coli, and Pseudomonas aeruginosa. Minimum inhibitory concentration studies demonstrated the resistance of bacteria to the peptide action and the peptide instability in bacterial growth conditions.
\end{abstract}

Keywords: antimicrobial peptides; peptide synthesis; solid-phase approach; bacteria resistance

\section{Introduction}

The discovery of antibiotics is considered one of the greatest and best achievements in the scientific world and for the pharmaceutical industry. For years, they have been the most effective treatment against one of the biggest causes of death worldwide, systemic infections, the result of the action of a wide spectrum of pathogenic microorganisms. However, nowadays, these are no longer a $100 \%$ effective solution in the fight against bacterial infections due to the development of resistance from both Gram-positive and Gram-negative bacteria, including: Staphylococcus aureus, Enterococcus spp., Pseudomonas aeruginosa, and Escherichia coli [1-3]. To battle this obstacle, some functional strategies were developed to replace the action of conventional antibiotics with biomolecules with similar pharmacological characteristics, like peptides with antimicrobial activity (AMPs).

The effectiveness of AMPs is reflected in their mechanisms of action, affecting cell membranes in different ways, changing their permeability, or causing the membrane to rupture entirely. Such mechanisms are not common to all types of peptides and depend on their molecular properties and the type of bacterial and/or cellular target, including DNA, RNA, regulatory enzymes, and other proteins. Generally, the damage caused to bacteria by AMPs is difficult to correct and the possibility that they develop resistance to these peptides is believed to be remote [4-6]. 
Peptaibols are a family of AMPs isolated from the fungal strain Trichoderma and have antibacterial and antifungal properties. The main characteristic of this type of AMP is the presence of non-proteinogenic amino acids which are not encoded by DNA, such as $\alpha$ aminobutyric acid (Aib) and isovaline (Iva). This class of amino acids is often used in peptides of pharmacological interest since they are not recognized by hydrolytic enzymes, improving their biodegradability and increasing their bioavailability $[7,8]$. One of the most unique AMPs in this family is Peptaibolin because it is the smallest in the peptaibol family, but at the same time, it has a three-dimensional structure comparable to the larger peptaibols. It contains an $\mathrm{N}$-terminal acetyl group and a $\mathrm{C}$-terminal phenylalaninol (Phol) residue, together with only four amino acids (Ac-Leu-Aib-Leu-Aib-Phol) (Figure 1). Crisma et al. studied Peptaibolin and concluded that this small peptide had antimicrobial activity, albeit moderate, in Gram-positive bacteria. Its mode of action is based on the permeabilization of the cell membrane causing its rupture. Through conformational studies by X-ray crystallography, it was detected that Peptaibolin has an extremely folded secondary $\alpha$-helix structure and its antimicrobial activity is directly related to this fact, since this conformation allows for aggregation, an unusual feature in peptides with few amino acid residues [9].<smiles>CC(=O)NC(CC(C)C)C(=O)NC(C)(C)C(=O)NC(CC(C)C)C(=O)NC(C)(C)C(=O)NC(CO)Cc1ccccc1</smiles>

Figure 1. Structure of the antimicrobial peptide (AMP) Peptaibolin containing an N-terminal acetyl group and a $C$-terminal phenylalaninol (Phol) residue, encompassing only four amino acid residues (Ac-Leu-Aib-Leu-Aib-Phol).

The synthesis of Peptaibolin and all peptaibols in general is significantly impaired by stereochemical impediment in residues such as Aib, where the reactivity during the coupling reaction is decreased compared to other amino acid residues. To overcome this difficulty, it is necessary to use a selection of suitable coupling reagents that allow the best possible activation of the carboxyl terminal of the amino acid Aib [10]. In this work, the combination of two groups of coupling reagents was studied, $N, N^{\prime}-$ Diisopropylcarbodiimide/1-Hydroxybenzotriazole (DIC/HOBt) and $N, N^{\prime}-$ Diisopropylcarbodiimide/Ethyl 2-cyano-2-(hydroxyimino)acetate (DIC/Oxima), to compare their reaction yields and purity using Solid Phase Peptide Synthesis assisted by Microwave heating (MW-SPPS) method, in a pre-loaded Phe-Wang resin. In addition, solubility and antimicrobial tests were performed.

\section{Experiments}

\subsection{Materials}

Microwave synthesis was performed on the manual peptide synthesizer Discover SPPS (CEM Corporation). The solid supports used were Fmoc-Phe-Wang resin with a functionalization degree of $0.51 \mathrm{mmol} / \mathrm{g}$ acquired from AAPPtec. The ${ }^{1} \mathrm{H}$ nuclear magnetic resonance spectra were obtained on the Bruker Avance III 400 device at a frequency of 400 $\mathrm{MHz}$, using the solvent peak as an internal reference, at $25^{\circ} \mathrm{C}$. The deuterated solvent used was deuterated chloroform $\left(\mathrm{CDCl}_{3} \mathrm{~d}_{6}\right)$ with a deuteration degree greater than $99.8 \%$ (Acros Organics). Coupling constants $(J)$ were obtained in Hertz $(\mathrm{Hz})$ and chemical shifts (ठ) in parts per million (ppm). Analytical High Performance Liquid Chromatography (HPLC) analysis was performed with a Licrospher 100 RP18 column $(5 \mu \mathrm{m})$ in an HPLC system composed of a Jasco PU-980 pump, coupled to a Shimadzu SPD-GAV UV/vis 
detector and a Shimadzu C-RGA Chromatopac recorder. The dry reagents and solvents were used as purchased commercially (AAPPtec, Louisville, KY, USA; Acros Organic, Geel, Belgium; Sigma Aldrich, St. Louis, MO, USA; Merck, Kenilworth, NJ, USA). Growth media Mueller Hinton broth (MHB) was obtained from CondaLab. Gram-negative E. coli (ATCC 25922) and P. aeruginosa (ATCC 25853) and Gram-positive S. aureus (ATCC 6538) and S. epidermidis (ATCC 35984) bacteria were supplied from American Type Culture Collection (ATCC).

\subsection{Synthesis of Peptaibolin by MW-SPPS on Wang Resin}

\subsubsection{DIC/HOBt as Coupling Reagents}

Starting from $1.1 \mathrm{~g}$ of Fmoc-Phe-Wang resin $(0.51 \mathrm{mmol} / \mathrm{g})$, Fmoc group was removed by adding $5 \mathrm{~mL}$ of a $20 \%$ piperidine solution in dimethylformamide (DMF) to the reaction vessel containing the resin. The vessel was placed with the optical fiber for temperature measurement in the microwave and the SPPS deprotection program was chosen at $75^{\circ} \mathrm{C}$ and 20 watts $(\mathrm{W})$ for $30 \mathrm{~s}$. After this initial deprotection, the $20 \%$ piperidine solution in DMF was filtered and $7 \mathrm{~mL}$ of this solution was added again, and the same program was selected for $3 \mathrm{~min}$. The solution was filtered and washes were performed: DMF $(3 \times)$ and methanol $(\mathrm{MeOH})(3 \times)$, repeating this washing cycle four times. Then, all amino acids were sequentially coupled by introducing Fmoc-Aib-OH, Fmoc-Leu-OH, Fmoc-Aib-OH, and Fmoc-Leu-OH sequentially. The $N$-protected amino acid ( 0.0028 mol, 5 equiv.), HOBt ( $0.0028 \mathrm{~mol}, 0.4756 \mathrm{~g}, 5$ equiv.), and DIC ( $0.0028 \mathrm{~mol}, 0.35 \mathrm{~mL}, 5$ equiv) were dissolved and the reaction mixture containing the amino acid Aib required a stirring period of $2 \mathrm{~h}$ and the reaction mixture containing the amino acid leucine (Leu) remained stirring for $5 \mathrm{~min}$. After two cycles of coupling with the conditions of $75^{\circ} \mathrm{C}$ and $20 \mathrm{~W}$ for $5 \mathrm{~min}$, the following washes were performed: $\mathrm{DMF}(3 \times)$ and $\mathrm{MeOH}(3 \times)$, three wash cycles.

Prior to the separation of the peptide from the resin, acetylation was carried out, in which the resin was suspended in $7 \mathrm{~mL}$ of dry DMF, $1 \mathrm{~mL}$ of $N, N$-Diisopropylethylamine (DIPEA) (14 equiv.), and then $0.4 \mathrm{~mL}$ of acetic anhydride ( 7 equiv.) were added. The mixture was left under stirring for $1.5 \mathrm{~h}$. After that period, the resin was washed with DMF (2×), MeOH (2×), dichloromethane (DCM) (3×), and ethyl ether (3×). The resin was dried in the desiccator at room temperature.

After obtaining the final sequence and acetylation, the peptide Ac-Leu-Aib-Leu-AibPhol was separated from the Wang resin. In a 3-port flask, sodium borohydride $\left(\mathrm{NaBH}_{4}\right)$ (5 equiv.) was suspended in dry tetrahydrofuran (THF) $(16 \mathrm{~mL} / \mathrm{g}$ resin) under nitrogen atmosphere, dry ethanol (EtOH) $(4 \mathrm{~mL} / \mathrm{g}$ resin), and lithium bromide ( $\mathrm{LiBr})$ (5 equiv.). The mixture was vigorously stirred for $15 \mathrm{~min}$ in an ice bath and a further $15 \mathrm{~min}$ at room temperature. The resin was added to the previous mixture and left to stir at room temperature for a period of $24 \mathrm{~h}$.

The separation of the resin from the reaction mixture was done through filtration into a porous plate funnel and washed with THF (2×), EtOH (2×), and ethyl acetate (EtOAc) $(2 \times)$, directly into a $100 \mathrm{~mL}$ round bottom flask. Acetic acid was added dropwise in order to eliminate all the borohydride present in the mixture. The solvent was evaporated without heating and proceeded to the extraction, using a combination of water $\left(\mathrm{H}_{2} \mathrm{O}\right)$ :EtOAc:saturated sodium chloride $(\mathrm{NaCl})$ solution $(3 \times)$. The organic phase was collected and dried using anhydrous magnesium sulfate $\left(\mathrm{MgSO}_{4}\right)$. After filtration, the solvent was evaporated to dryness without heating. Ethyl ether was added and placed in the cold. The solution was centrifuged until a white solid was obtained.

\subsubsection{DIC/Oxima as Coupling Reagents}

Starting from $1.1 \mathrm{~g}$ of Fmoc-Phe-Wang resin $(0.51 \mathrm{mmol} / \mathrm{g})$, the protective group was removed by adding $5 \mathrm{~mL}$ of a $20 \%$ piperidine solution in DMF to the reaction vessel containing the resin. The vessel was placed with the optical fiber for temperature measurement in the microwave and the SPPS deprotection program was chosen at $75^{\circ} \mathrm{C}$ 
and $20 \mathrm{~W}$ for $30 \mathrm{~s}$. After this initial deprotection, the $20 \%$ piperidine solution in DMF was filtered and $7 \mathrm{~mL}$ of this solution was added again, and the same program was selected again for $3 \mathrm{~min}$. The solution was filtered and washes were performed, DMF (3x) and $\mathrm{MeOH}(3 \mathrm{x})$, repeating this washing cycle 4 times. Then, all amino acids were sequentially coupled by introducing Fmoc-Aib-OH, Fmoc-Leu-OH, Fmoc-Aib-OH, and Fmoc-Leu$\mathrm{OH}$, sequentially. The $N$-protected amino acid ( 0.0028 mol, 5 equiv.), Oxima ( 0.0028 mol, 0.3986 g, 5 equiv.), and DIC ( $0.0028 \mathrm{~mol}, 0.35 \mathrm{~mL}, 5$ equiv.) were dissolved, and the reaction mixture containing the amino acid Aib required a stirring period of $2 \mathrm{~h}$ and the reaction mixture containing the amino acid Leu remained stirring for $5 \mathrm{~min}$. After two cycles of coupling with the conditions of $75^{\circ} \mathrm{C}$ and $20 \mathrm{~W}$ for $5 \mathrm{~min}$, the following washes were performed: $\mathrm{DMF}(3 \times)$ and $\mathrm{MeOH}(3 \times), 3$ wash cycles. Prior to the separation of the peptide from the resin, acetylation was carried out, in which the resin was suspended in $7 \mathrm{~mL}$ of dry DMF, $1 \mathrm{~mL}$ of DIPEA (14 equiv.), and then $0.4 \mathrm{~mL}$ of acetic anhydride (7 equiv.) were added. The mixture was left under stirring for $1.5 \mathrm{~h}$. After that period, the resin was washed with DMF $(2 \times), \mathrm{MeOH}(2 \times), \mathrm{DCM}(3 \times)$, and ethyl ether $(3 \times)$. The resin was dried in the desiccator at room temperature.

After obtaining the final sequence and acetylation, the peptide Ac-Leu-Aib-Leu-AibPhol was separated from the Wang resin. In a 3-port flask, $\mathrm{NaBH}_{4}$ (5 equiv.) was suspended in dry THF $(16 \mathrm{~mL} / \mathrm{g}$ resin) under nitrogen atmosphere, dry ethanol $(4 \mathrm{~mL} / \mathrm{g}$ resin), and $\mathrm{LiBr}$ (5 equiv.). The mixture was vigorously stirred for $15 \mathrm{~min}$ in an ice bath and a further $15 \mathrm{~min}$ at room temperature. The resin was added to the previous mixture and left to stir at room temperature for a period of $24 \mathrm{~h}$.

The separation of the resin from the reaction mixture was done through filtration into a porous plate funnel and washed with THF (2×), EtOH $(2 \times)$, and EtOAc (2×), directly into a $100 \mathrm{~mL}$ round bottom flask. Acetic acid was added dropwise in order to eliminate all the borohydride present in the mixture. The solvent was evaporated without heating and proceeded to the extraction, using a combination of $\mathrm{H}_{2} \mathrm{O}$ :EtOAc:saturated $\mathrm{NaCl}$ solution $(3 \times)$. The organic phase was collected and dried using anhydrous $\mathrm{MgSO}_{4}$. After filtration, the solvent was evaporated to dryness without heating. Ethyl ether was added and placed in the cold. The solution was centrifuged until a white solid was obtained.

\subsection{Peptaibolin Caracterization: Proton Nuclear Magnetic Resonance ( ${ }^{1} H$ NMR)}

For structural confirmation, $5 \mathrm{mg}$ of peptide was dissolved in $500 \mu \mathrm{L}$ of CDCL3d 6 and transferred to an NMR tube and NMR spectrum was recorded at $400 \mathrm{MHz}$.

\subsection{Peptaibolin Caracterization: High Performance Liquid Chromatography (HPLC)}

To confirm the purity, three eluent solutions were prepared. Filtering all solvents, $300 \mathrm{~mL}$ of the eluent solution acetonitrile/water $\left(\mathrm{ACN} / \mathrm{H}_{2} \mathrm{O}\right)(1: 1), \mathrm{ACN} / \mathrm{H}_{2} \mathrm{O}(2: 1)$, and $\mathrm{ACN} / \mathrm{H}_{2} \mathrm{O}(1: 2)$ was prepared, adding $0.1 \%$ trifluoroacetic acid (TFA), and all solutions were placed in an ultrasonic bath for $20 \mathrm{~min}$.

\subsection{Solubility Tests Preparation}

Several solvents have been tested so that the dissolution of Peptaibolin takes place. For each solvent tested, a specific peptide mass was weighed and tried to dissolve in $1 \mathrm{~mL}$ of solution. For the combination of $10 \%$ dimethyl sulfoxide (DMSO) in $\mathrm{H}_{2} \mathrm{O}$ (2 mg); for $10 \%$ hydrochloric acid (HCL)/ $\mathrm{H}_{2} \mathrm{O}(1.9 \mathrm{mg})$; for $100 \% \mathrm{HCL}$ (1.8 mg); for phosphate-buffered saline (PBS) (2.4 mg); for $\mathrm{NaCl} / \mathrm{H}_{2} \mathrm{O}(2 \mathrm{mg})$; for Acetic acid/ $\mathrm{H}_{2} \mathrm{O}(1.9 \mathrm{mg})$; for $10 \%$ $\mathrm{CDCL}_{3}(2 \mathrm{mg})$; and for $\mathrm{ACN} / \mathrm{H}_{2} \mathrm{O}(2.1 \mathrm{mg})$.

\subsection{Minimum Inhbitory Concentration (MIC)}

Working solutions at $8 \mathrm{mg} / \mathrm{mL}$ were prepared using the most suitable solvent. Aliquots were added to the first column of 96-well plates in a volume of $100 \mu \mathrm{L}$. Serial dilutions (1:2) were made with MHB in the consecutive wells, to a final volume of $50 \mu \mathrm{L}$. Then, 
to each of these wells, $50 \mu \mathrm{L}$ of the bacteria suspensions prepared at $2 \times 10^{7} \mathrm{CFUs} / \mathrm{mL}$ in $\mathrm{MHB}$ were added (inoculated from one colony and grown overnight at $37{ }^{\circ} \mathrm{C}$ and 100 rpm), meaning the starting peptide concentration in contact with the bacteria was at 4 $\mathrm{mg} / \mathrm{mL}$. Agent-free bacteria suspensions (positive) and culture media (negative) were used as controls. Absorbance readings at a wavelength of $600 \mathrm{~nm}$ (EZ READ 2000 Microplate Reader, Biochrom, UK) were made before and after plate incubation for $24 \mathrm{~h}$ at 37 ${ }^{\circ} \mathrm{C}$ and $100 \mathrm{rpm}$. The MIC value for each peptide/bacteria combination was established as the concentration at which bacteria did not show any growth, determined visually, and confirmed by the differences in absorbance readings.

\section{Results and Discussion}

\subsection{Synthesis of Peptaibolin by MW-SPPS on Wang Resin}

Peptaibolin was synthesized according to the MW-SPPS method where each amino acid is sequentially coupled with the aid of a combination of coupling reagents in order to favor the activation of the carboxylic group and potentiate the formation of the peptide bond between two amino acid residues. Despite the fact that Peptaibolin is a widely studied peptide, which mechanisms of action and antimicrobial activity have already been proven and further studies have been already performed by replacing the amino acid Aib with its analogues to potentiate its activity, the search for different coupling reagent combinations has never been much addressed. Two combinations were tested: DIC/HOBt and DIC/Oxima. After obtaining the white solid by centrifugation and after a drying period in a desiccator, the mass obtained from each peptide was weighed and their yields were calculated. It was proved that the combination of DIC/Oxima coupling reagents had a higher yield as well as a higher purity, confirmed by the retention time obtained by the analytical HPLC technique using $\mathrm{ACN} / \mathrm{H}_{2} \mathrm{O}(1: 1)+0.1 \%$ TFA as eluent (Table 1 ).

Table 1. Comparison between the two coupling reagent combinations in terms of obtained mass, reaction yield, and retention time purity.

\begin{tabular}{cccc}
\hline Coupling Reagents & Mass (g) & Yeld (\%) & Retention Time (min) \\
\hline DIC/HOBt & 0.1222 & 40.6 & 6232 \\
DIC/Oxima & 0.1520 & 50.0 & 6942 \\
\hline
\end{tabular}

Structural confirmation was made only by ${ }^{1} \mathrm{H}$ NMR for each peptide synthesized with different coupling reagents where it was proved that both peptides contained all the amino acids coupled in the right positions.

DIC/HOBt: RMN de ${ }^{1} \mathbf{H}\left(\mathrm{CDCl}_{3} \mathrm{~d}_{6}, 400 \mathrm{MHz}\right) \delta_{\mathrm{H}}=0.90-1.00\left(12 \mathrm{H}, \mathrm{m}, 4 \times \mathrm{CH}_{3}-\mathrm{Leu}\right)$; $1.37\left(3 \mathrm{H}, \mathrm{s}, J=6.8 \mathrm{~Hz}, \mathrm{CH}_{3}-\mathrm{Aib}\right) ; 1.38$ (3H, s, J = 6.4 Hz, CH3-Aib); 1.48 (3H, s, CH3-Aib); 1.54 (3H, s, CH3-Aib); 1.58-1.89 (6H, m, $\left.\beta \mathrm{CH}_{2}-\mathrm{Leu}+\gamma \mathrm{CH}-\mathrm{Leu}\right) ; 2.14$ (3H, s, $\left.\mathrm{CH}_{3} \mathrm{CO}\right)$; $2.77-$ $2.83\left(2 \mathrm{H}, \mathrm{m}, \mathrm{CH}_{2}-\mathrm{Phe}\right) ; 3.62-3.69$ (2H, m, CH$\left.{ }_{2} \mathrm{OH}\right) ; 3.96$ (1H, s, $\left.\alpha \mathrm{CH}-\mathrm{Leu}\right) ; 4.02-4.08$ (1H, m, $\alpha$ CH-Leu); 4.29 (1H, s, $\alpha$ CH-Leu); 7.17-7.30 (5H, m, CH-Phol); 7.85 (1H, s, NH-Leu); $8.02(1 \mathrm{H}, \mathrm{s}, \mathrm{NH}) ; 8.11(1 \mathrm{H}, \mathrm{s}, \mathrm{NH})$.

DIC/Oxima: RMN de ${ }^{1} \mathbf{H}\left(\mathrm{CDCl}_{3} \mathrm{~d}_{6}, 400 \mathrm{MHz}\right) \delta_{\mathrm{H}}=0.97-1.00$ (12H, m, 4xCH$\left.-\mathrm{Leu}\right)$; 1.38 (3H, s, CH3-Aib); 1.39 (3H, s, $\left.\mathrm{CH}_{3}-\mathrm{Aib}\right) ; 1.48$ (3H, s, $\left.\mathrm{CH}_{3}-\mathrm{Aib}\right) ; 1.54$ (3H, s, $\left.\mathrm{CH}_{3}-\mathrm{Aib}\right)$; 1.58-1.89 (6H, m, $\left.\beta \mathrm{CH}_{2}-\mathrm{Leu}+\gamma \mathrm{CH}-\mathrm{Leu}\right) ; 2.14\left(3 \mathrm{H}, \mathrm{s}, \mathrm{CH}_{3} \mathrm{CO}\right) ; 2.73-2,83\left(5 \mathrm{H}, \mathrm{m}, \beta \mathrm{CH}_{2}-\right.$ Phe); 3.61-3.72 (2H, m, CH $2 \mathrm{OH}) ; 3.96(1 \mathrm{H}, \mathrm{s}, \alpha-\mathrm{CH}) ; 4.02-4.08(1 \mathrm{H}, \mathrm{m}, \alpha \mathrm{CH}-\mathrm{Leu}) ; 4.29(1 \mathrm{H}$, s, $\alpha$-CH-Leu); 7.15-7.30 (5H, m, CH-Phol); $7.86(1 \mathrm{H}, \mathrm{s}, \mathrm{NH}) ; 8.06(1 \mathrm{H}, \mathrm{s}, \mathrm{NH}) ; 8.15(1 \mathrm{H}, \mathrm{s}, \mathrm{NH})$.

\subsection{Evaluation of Solubility Properties of Peptaibolin}

The solubility of an AMP is an important factor and it is crucial that the peptide is soluble in suitable and compatible solvents for antimicrobial tests. The use of toxic solvents is not interesting for this type of test since they cannot be applied in a biological context and therefore, cannot be biomedically applied. Solubility tests were performed only on the peptide synthetized with DIC/Oxima, mostly because of the highest amount 
of mass and yield. The most suitable solvent should be $100 \% \mathrm{H}_{2} \mathrm{O}$ due to its inert properties, being sure that it would not interfere with the antibacterial results. However, it was concluded that the peptide was not soluble in water, requiring the addition of other types of organic solvents or even the dissolution of the peptide in a total volume of organic solvents (Table 2).

Table 2. Combinations of solvents tested and the effects obtained on Peptaibolin in a total volume of $1 \mathrm{~mL}$ solution.

\begin{tabular}{cc}
\hline Solvents Tested $\left(\mathbf{V}_{\mathbf{T}}=\mathbf{1 ~} \mathbf{~ m L}\right)$ & Dissolution Effect \\
\hline $10 \% \mathrm{DMSO} / \mathrm{H}_{2} \mathrm{O}$ & Soluble \\
$\mathrm{ACN} / \mathrm{H}_{2} \mathrm{O}$ & Dissolves only with large amounts of ACN \\
$\mathrm{NaCl} / \mathrm{H}_{2} \mathrm{O}$ & Does not dissolve \\
Acetic Acid/ $\mathrm{H}_{2} \mathrm{O}$ & Peptide precipitation \\
$\mathrm{PBS}$ & Does not dissolve \\
$10 \% \mathrm{HCl} / \mathrm{H}_{2} \mathrm{O}$ & Does not dissolve \\
$100 \% \mathrm{HCL}$ & Does not dissolve \\
$100 \% \mathrm{H}_{2} \mathrm{O}$ & Does not dissolve \\
$10 \% \mathrm{CDCl}_{3}$ & Partially soluble \\
\hline
\end{tabular}

\subsection{Antibacterial Assessment}

MIC evaluations were conducted using $10 \%$ DMSO solvent in water. This was found as the most suitable solvent for the peptide and as such was applied in contact with the bacteria. After $24 \mathrm{~h}$ of incubation, precipitates were detected in the most Peptaibolin concentrated wells, namely those containing $4 \mathrm{mg} / \mathrm{mL}$ of the peptide solution. Bacteria was also found to grow over the incubation period. Data reported no action against the selected microorganisms, meaning that if it was possible to find an MIC for this peptide, it would be superior to $4 \mathrm{mg} / \mathrm{mL}$. In terms of biomedical or pharmacological applications, this concentration is considered too elevated and, as such, not suitable for a cost-effective mass production.

\section{Conclusions}

Although the discovery of Peptaibolin as an AMP is not a recent topic in scientific research and there have been several studies focusing on its optimization, this peptide is most often synthesized according to standard procedures and without varying its combination of coupling reagents. Nowadays, there are a variety of coupling reagents commercially available from the most traditional carbodiiamides, such as DIC, which is most frequently used in SPPS, to auxiliate nucleophiles such as HOBt. According to the results obtained, it can be concluded that the DIC/Oxima combination, in addition to maintaining the characteristics of Peptaibolin, provides better yields with the same level of purity. Furthermore, this alternative is even more positive because it replaces the traditional HOBt, which has explosive characteristics. Solubility tests were also performed to study the behavior of Peptaibolin in various solvents and to test its solubility. Being a small peptide and showing nonpolar characteristics, it was expected that its dissolution on $\mathrm{H}_{2} \mathrm{O}$ would be an obstacle, which has been proven, since this peptide is only soluble in organic solvents or in organic solvents in combination with $\mathrm{H}_{2} \mathrm{O}$, making it unsuitable for biomedical applications as AMP. Its lack of antibacterial activity was also proven with a certain amount of Peptaibolin being dissolved in $10 \% \mathrm{DMSO} / \mathrm{H}_{2} \mathrm{O}$ (the most promising solvent). Microbiological tests were carried out on Gram-positive bacteria and Gram-negative bacteria. However, MIC studies demonstrated the resistance of bacteria to the peptide action and the peptide instability in bacterial growth conditions. 
Author Contributions: A.R.M.R. performed the experiments; A.R.M.R., H.P.F., S.P.G.C., and S.M.M.A.P.-L. discussed the results; H.P.F., S.P.G.C., and S.M.M.A.P.-L. acquired the funding; H.P.F. and S.M.M.A.P.-L. supervised the work. All authors have read and agreed to the published version of the manuscript.

Funding: The authors acknowledge Fundação para a Ciência e Tecnologia-FCT (Portugal) for funding through CQUM (UID/QUI/00686/2020) and project PTDC/QUI-COL/28052/2017. The NMR spectrometer Bruker Avance III 400 is part of the National NMR Network and was purchased within the framework of the National Program for Scientific Re-equipment, contract REDE/1517/RMN/2005 with funds from POCI 2010 (FEDER) and FCT. Authors also acknowledge FCT for funding the project PEPTEX with reference PTDC/CTM-TEX/28074/2017 (POCI-01-0145-FEDER-028074). They acknowledge project UID/CTM/00264/2021 of Centre for Textile Science and Technology (2C2T), funded by national funds through FCT/MCTES.

Institutional Review Board Statement: Not applicable.

Informed Consent Statement: Not applicable

Conflicts of Interest: The authors declare no conflicts of interest.

\section{References}

1. Dosler, S. Antimicrobial Peptides: Coming to the End of Antibiotic Era, the Most Promising Agents. Istanbul J. Pharm. 2017, doi:10.5152/istanbuljpharm.2017.0012.

2. Laxminarayan, R.; Duse, A.; Wattal, C.; Zaidi, A.K.M.; Wertheim, H.F.L.; Sumpradit, N.; Vlieghe, E.; Hara, G.L.; Gould, I.M.; Goossens, H.; et al. Antibiotic Resistance-the Need for Global Solutions. Lancet Infect. Dis. 2013, doi:10.1016/S14733099(13)70318-9.

3. Rossolini, G.M.; Arena, F.; Pecile, P.; Pollini, S. Update on the Antibiotic Resistance Crisis. Curr. Opin. Pharmacol. 2014, doi:10.1016/j.coph.2014.09.006.

4. Hollmann, A.; Martinez, M.; Maturana, P.; Semorile, L.C.; Maffia, P.C. Antimicrobial Peptides: Interaction with Model and Biological Membranes and Synergism with Chemical Antibiotics. Front. Chem. 2018, 6, 204, doi:10.3389/fchem.2018.00204.

5. Pushpanathan, M.; Gunasekaran, P.; Rajendhran, J. Antimicrobial Peptides: Versatile Biological Properties. Int. J. Pept. 2013, 2013, 675391, doi:10.1155/2013/675391.

6. Felgueiras, H. Antimicrobial Peptides in Infected Wounds. In Research Trends of Microbiology; MedDocs Publishers LLC: Reno, NV, USA, 2019; doi:10.33582/research-trends-of-microbiology/antimicrobial-peptides-in-infected-wounds.

7. Das, S.; Ben Haj Salah, K.; Djibo, M.; Inguimbert, N. Peptaibols as a Model for the Insertions of Chemical Modifications. Arch. Biochem. Biophys. 2018, 658, 16-30, doi:10.1016/j.abb.2018.09.016.

8. Castro, V.I.B.; Carvalho, C.M.; Fernandes, R.D.V.; Pereira-Lima, S.M.M.A.; Castanheira, E.M.S.; Costa, S.P.G. Peptaibolin Analogues by Incorporation of $\alpha, \alpha$-Dialkylglycines: Synthesis and Study of Their Membrane Permeating Ability. Tetrahedron 2016, 72, 1024-1030, doi:10.1016/j.tet.2015.12.079.

9. Crisma, M.; Barazza, A.; Formaggio, F.; Kaptein, B.; Broxterman, Q.B.; Kamphuis, J.; Toniolo, C. Peptaibolin: Synthesis, 3DStructure, and Membrane Modifying Properties of the Natural Antibiotic and Selected Analogues. Tetrahedron 2001, 57, 28132825, doi:10.1016/S0040-4020(01)00124-7.

10. Ben Haj Salah, K.; Inguimbert, N. Efficient Microwave-Assisted One Shot Synthesis of Peptaibols Using Inexpensive Coupling Reagents. Org. Lett. 2014, 16, 1783-1785, doi:10.1021/ol5003253. 